\title{
Morena Mohlomi le Badimo: Reading decolonial articulations into the intellectual property law curriculum
}

Ntando Sindane ${ }^{1}$ - University of the Free State

\section{Abstract}

Journal of Decolonising Disciplines

Volume 2, Issue 1 (2020)

eISSN: 2664-3405

DOI: https://doi.org/10.35293/jdd.v2i1.40

The South African Council on Higher Education (CHE) expresses itself cogently in affirming the validity of the calls specifically to decolonise the LLB curriculum (2017). Public discourse and the CHE report present an emerging clarion call for the academy critically to engage the question of decolonisation of the curriculum. This article proposes Transmodernity as a methodological endeavour towards engaging African epistemologies in an effort to find alternatives in teaching various intellectual property law concepts. To tease out the fundamental decolonial question of how the dismembered can be re-membered, the paper tests the theory of Mohlomism and its applicability to the intellectual property law curriculum. Mohlomi was a mentor to the king of Lesotho, Morena Moshoeshoe I. Mohlomi would travel around Southern Africa teaching society his philosophy of truthfulness, justice, peace, the love of man and of sane humanism. Re-membering the Being of the proverbial 'other' reverses the effect of the prevailing legacy of epistemicide in the curriculum and may gradually lead to a transformed legal pedagogy. The article discerns decolonisation as a project that inter alia seeks to create a pluriversal intellectual community that embosoms the epistemic traditions of the global South.

Keywords: Decoloniality, Intellectual Property Law, Mohlomism, Badimo, Transmodernity.

1 Ntando Sindane LLB LLM (Unisa), Lecturer, Department of Private Law, University of the Free State,SindaneNP@ufs.ac.za. Some parts of this article are drawn from the research undertaken in pursuance of my LLM thesis titled, "The call to decolonise higher education: copyright law through an African lens". I wish to sincerely thank Richard Shay, Sunelle Geyer, Thuli Zulu, Coenraad Visser and Mavis Nyatlo for their insightful comments on earlier drafts of this article. The usual caveats apply. 


\section{Introduction}

The debate on the transformation and development of the South African LLB curriculum stems from the judiciary complaining that most LLB graduates cannot read nor write and lack basic numeracy skills. ${ }^{2}$ Subsequent investigations into the state of the provision of the LLB curriculum had lain bare the truth that there are challenges facing this curriculum. The dialogue surrounding LLB education is complicated by demands of university and TVET students in 2015-2016 protesting for free education, free not only in terms of access but also from capitalist, Eurocentric and colonial demands (Manzini 2017).

Admittedly, the calls for decolonisation predate \#FeesMustFall. However, as far as the LLB is concerned, these protests brought to light two indispensable questions: What is the content taught to students? and how is it taught? (Himonga \& Diallo 2017). The issues of curriculum transformation and legal pedagogy have been contested terrain since the dawn of democracy in South Africa. Dlamini (1992) is among the first to problematise the LLB curriculum in this period, arguing that the curriculum is not context-sensitive, and has an alienating effect particularly on black students. Dlamini (1992: 595) accordingly opines that an engaged LLB curriculum is one that expressly inculcates a strong sense of social justice in a student. Quinot (2012) takes the discussion further by insisting that transformative legal education should be bedrock of the LLB curriculum; such a renewed curriculum would be based on the existing theorisation on transformative constitutionalism, meaning that new areas of law (such as politics, sociology and history) must be accommodated in the curriculum, thus shifting it away from legal formalism. Quinot (2012: 419, 421 \& 423) summarises transformative legal education as an action of moving from transmission to construction, the former being the pedagogy of the teacher who transmits knowledge to an empty student; the latter being teaching through constructing new knowledge with both the teacher and the student acting as knowledge creators and partners in knowledge production. Zitzke (2014: 64) intervenes in the discourse of legal education by arguing that the challenge with current pedagogical patterns lies in conservative legal traditions in terms of which teachers train students to become

2 Council on Higher Education. 30 November 2018. The State of the provision of the Bachelor of Laws (LLB) qualification in South Africa. 
docile bodies fit to serve at the behest of capitalist interests. Modiri (2014:42) goes further by insisting that the crisis is not merely with the law curriculum, but also with the law itself; he posits that legal education is linked to profit and the marketability of law graduates. In confronting these problems, Zitzke (2018:494) proposes a decolonial turn in the LLB curriculum, defining decolonisation as '[a] commitment to Africanization through conceptual decolonization' He explains that Africanisation means centring African thought in the study of each discipline to make it contextually sensitive to Africa's epistemological traditions and related ontologies (Zitzke 2018: 509).

The Council on Higher Education set the process in motion to review the LLB curriculum in 2017, culminating in a comprehensive report titled The State of the provision of the Bachelor of Laws (LLB) qualification in South Africa. The report calls for an extensive transformation of legal education in South Africa, opening up space to test theories for decolonising of the LLB curriculum. The report's findings point towards new ways of thinking about how the law is taught, insisting on transformative constitutionalism as a foundation of a transformed LLB curriculum, whilst also expressly paving a way for decolonised articulations of legal pedagogy in its curriculum content and delivery mode.

This article advocates for the inclusion of newer ideas in the LLB curriculum, seeking to ensure the gradual transformation of the LLB. The objective of decolonial articulations in intellectual property law is to dismantle and deconstruct the colonial lack of receptiveness to alternative epistemologies (Motshabi 2018). This article further separates the curriculum from the legal system, focusing epistemic and pedagogical questions, rather than the application of the law by the courts. Although there is an overlap between the two, it is helpful to be specific in articulating the operative scope of decoloniality in all spheres of the colonised society.

The overarching theme in decolonial articulations presents a discourse on epistemicide, framing the coloniser as the killer of the knowledge(s) of colonised bodies. To reverse the epistemicidal legacy is to go to the graves wherein African knowledge(s) are buried, open them up and resuscitate these African knowledge(s). This method, although submitted in the metaphorical sense, is one response to the fundamental decolonial questions that Ndlovu-Gatsheni (2015a:23) raises: 'How can the "dismembered" people be "remembered"? How can they relaunch themselves from the world of "non-being" into the world of language and knowledge?' The reversal of epistemicide and subsequent re-membering of the dismembered involves 
a restorative recovery project of colonised bodies being given the power of owning and naming their own realities using their own epistemic perspectives (NdlovuGatsheni 2015a). Just as genocide is the deliberate killing of a large group of people, especially those of a nation or ethnic group, epistemicide is the deliberate killing of these people's knowledge systems (Zitzke 2017). The non-Being of a colonised body allows the coloniser to dispense with the knowledge(s) of local communities in an African context.

To reverse epistemicide, law teachers, researchers and historians need to go back to pre-colonial Africa and look for those knowledge(s) of African societies prior to colonial disturbance. The act of going back to pre-colonial Africa does not mean that decoloniality seeks to go to the stone-age; it instead seeks epistemic justice by way of uncovering those knowledges that were silenced through epistemicide. Zitzke (2017: 191) suggests that ' $[\mathrm{p}]$ art of the epistemicidal effects of colonisation certainly related to the death of culture and language - it must be emphasised that a crucial effect was the discarding of African law, seen as inferior and barbaric and its replacement with a Dutch-inspired legal system, perceived to bring order to orderless African tribes'.

Indeed, part of reversing the effect of epistemicide is focusing our attention on the question of language. Ngũgĩ wa Thiongo (1986) wrote Decolonizing the mind: The politics of language in African literature in the context of African literature. In an epistemic inquiry, Ngũgĩ recounts the violence of the classroom in which colonised people were met with the violence of having to be taught in a foreign language and be tacitly conditioned to accept that their own language does not matter or is not good enough for higher education or literature. Wa Thiongo (1986:4) counsels that the language question is vital to the decolonial project, he further posits that 'the choice of language and the use to which language is put is central to a people's definition of themselves in relation to their natural and social environment, indeed in relation to the entire universe. His assertions validate what scholarship around the coloniality of Being and of knowledge represents in its calls for the re-membering of colonised bodies. This reading of Ngũgĩ is thus one of re-membering the dismembered colonised body by advocating for the choice to be taught in one's language. NdlovuGatsheni (2015a:24) paraphrases Wa Thiongo, insisting that '[d]ecoloniality [should be understood] to be a search for a liberating perspective aimed at facilitating selfunderstanding (seeing ourselves clearly) after centuries of suffering dismemberment and alienation'. The essence of decolonisation becomes to re-member the colonised body as a Being by engaging in practical actions that affirm them as thinkers that are 
capable of producing knowledge.

The argument of this paper is propounded in five sections: following from this introduction, the second sections reads decolonial articulations and their intersection with the law curriculum. This section is intended to provide a theoretical framework that this paper relies on, enabling a decolonised enunciation of the curriculum. The third section juxtaposes the Eurocentric incentive theory with the unique African philosophy of Mohlomism in an endeavour explicitly to re-articulate the epistemic traditions of the global South, proving that the dismembered subalterns are Beings, worthy of solving complex societal questions. The fourth section problematises labour theory as it relates to the author in copyright law and its inability to respond to Africa's conception of communal authorship. Modimo and Badimo are an alternative explanation of extant colonial conceptualisations in copyright law. The fifth section concludes this paper.

\section{DECOLONIAL ARTICULATIONS}

The goal [of decolonising] is to better understand the nexus of knowledge, power, and being that sustains an endless war on specific bodies, cultures, languages, traditions, beliefs knowledge(s), nature, and peoples, as well as to help evade and oppose multiple forms of decadent responses (Gordon 2014), including narrow views within decolonial movements themselves. (Maldonado-Torres 2016: 2)

Bhambra (2014: 120) argues that both post-colonialism and decoloniality are necessary because of the depredations of colonialism and hence offer the possibility of a new geopolitics of knowledge. Decolonisation is an inevitably violent phenomenon in that it entails the de-centring of long standing hegemonic orders. The de-centering of long standing hegemonic orders dismantles Eurocentrism in higher education and the curriculum, presenting a violence to both the colonised and the coloniser.

In the conversations about the impact of colonial relations of power, there is a need to revisit the standard understanding of Being. Maldonado-Torres (2016: 2) uses the Cartesian formulation of the existential statement 'cogito ergo sum', which translates as 'I think, therefore I am'. As long as 150 years before Descartes' ontological formulation, European thinking was encapsulated in the maxim 'ego conquiro' which means, if one reads in the elliptical ('ergo sum'), 'I conquer, therefore I am' (Grosfoguel 2002). This reading suggests that Europe had assumed a God-like 
status, placing itself at the foundation of knowledge, acting as an imperial-being at the centre of the world because they had already conquered it (Grosfoguel 2002). It is worth noting that the 'I think' and the 'I am' formulation is actually a misnomer in African ontological formulations (Cornell \& Van Marle 2005). Apart from its individualistic herrings, as presented by the "I think" and the "I am", the Cartesian ontological axiom becomes a misfit in African epistemic traditions because the latter bases its understanding Being in pluversal conceptions that embosom communities, spiritualties, and related cosmologies.

The question of Being extends from the latter part of Descartes' ontological axiom. Descartes means that before a person can be that person needs to think. To think is cast as a prerequisite to Being. The essence of Being is embedded in a person's ability to think or possess mental faculties. Animals, plants and other living and non-living things are not Being precisely because they are regarded in the Cartesian paradigm as unthinking (Maldonado-Torres 2016).

Descartes' formulation on what Being is and what should define it, when inverted, is used to exclude colonised bodies from Being. Maldonado-Torres (2016:251) insists that the coloniser was able to exclude his colonial subjects from Being because the colonial project included the rejection of the Beinghood of colonised bodies, and in the context of Africa colonised bodies means black people. The colonial side of Being therefore cannot be divorced from the colour line (Grosfoguel 2002).

The coloniser is conscious of himself as a Being and aware that this consciousness included the deliberate dismembering of the colonised body. In this way the colonised body was reduced to a non-thinking species. The self-misrecognition of non-Being on the part of the colonised serves as a starting point when thinking about coloniality of Being (Maldonado-Torres 2016).

An inquiry into power relations between the coloniser and the colonised includes ascertaining patterns of knowledge production. Ndlovu-Gatsheni (2013: 5) asserts that decoloniality requires critical thinking about who generates knowledge, how it is generated and what purpose it serves. Ndlovu-Gatsheni's study (2013) investigates how knowledge(s) have been used in the past to disempower communities and peoples. Ndlovu-Gatsheni (2013: 5) elaborates that '[the] concept of coloniality of knowledge ... focuses on teasing out epistemological issues, the politics of knowledge generation, as well as questions of who generates which knowledge, and for what purpose'.

New thinking (Nabudere 2003) on how the law is taught in South African 
universities is imperative for the decolonisation project. Decoloniality suggests heterarchical thinking as an endeavour to conceptualise social structures with a new vocabulary that breaks ranks with the prevailing definitional paradigm (Grosfoguel 2002). Heterarchical thinking avows that extant law and social sciences follow a colonial logic of assuming a single overarching hierarchy in knowledge production (Grosfoguel 2002).

Although developing countries attempt to exploit intellectual property in their own right, they find themselves with the inheritance of protectionist laws from colonial days (Cornish 1989; Kelbrick 2008). Hetararchical thinking proposes the introduction of previously silenced forms of knowledge into the curriculum (Grosfoguel 2002). Differentiation is a methodology that allows African methods of protecting creative works that currently fall under the scope of copyright law to be uncovered. Grosfoguel (2002:208) advocates differentiation as expressed in the concept of Transmodernity, arguing that, 'trans' is an invitation to go beyond Eurocentric modernity. Transmodernity asserts the decolonial desire for the academy expressly to move beyond Eurocentric canons of thought and allow subaltern voices to feature in the curriculum.

Transmodernity calls for epistemic diversity as a prerequisite to critical thinking about the epistemic traditions of the global South (Grosfoguel 2003). Transmodernity does not embrace a value-neutral posture towards the curriculum, but expressly sets out to transcend European modernity (Grosfoguel 2003). Grosfoguel (2002:208) argues that the masculine Western myth that knowledge production is neutral, universal and un-positioned has been vanquished by decolonial scholarship showing that production of knowledge is inextricably intertwined with global politics and Eurocentric hierarchies. Grosfoguel (2003: 88) insists that Eurocentric modernity monopolised the definitions of democracy, human rights, economy, and others, and that Transmodernity seeks to provide a space for these definitions to be recast according to pluriversal epistemic traditions.

Coloniality of power invites a study of how the world is divided into the Zoneof-Being and the Zone-of-Nonbeing (Madlingozi 2017). Scholars use this concept to analyse the modern operations of power and how the world works. Coloniality of power is used as a reference point in assessing how the global political setting is constructed according to sexist, patriarchal, capitalist hegemonic orders that create a hetero-normative imperial power structure (Ndlovu-Gatsheni 2015).

Coloniality of power situates the production of knowledge with the network of 
the global power struggles that define curriculum development and transformation. According to Grosfoguel (2002: 218), coloniality of power posits the 'culture vs economy' dilemma which appears when economic relations in social processes are privileged over cultural and ideological aspirations. Coloniality of power integrates the multiplicity of cultural, political and economic relations that are mediated in a neo-liberal capitalist dispensation (Grosfoguel 2002).

Decolonisation seeks to act as an antithesis to coloniality and not colonialism. Maldonado-Torres (2007: 4) accordingly qualifies the distinction between colonialism and coloniality as follows:

Coloniality is different from colonialism. Colonialism denotes a political and economic relation in which the sovereignty of a nation or a people rests on the power of another nation, which makes such nation an empire. Coloniality, instead, refers to long-standing patterns of power that emerged as a result of colonialism, but that define culture, labour, intersubjective relations, and knowledge production well beyond the strict limits of colonial administrations. Thus, coloniality survives colonialism. It is maintained alive in books, in the criteria for academic performance, in cultural patterns, in common sense, in the self-image of people, in aspirations of self, and so many other aspects of our modern experience.

The appreciation of this distinction is critical because it acknowledges the reality that although colonialism has been defeated in most of Africa (with the notable exception of the Western Sahara), its effects, legacy and remnants remain deeply entrenched in all aspects of our present experience (Ncube 2016).

Ndlovu-Gatsheni (2015b: 485-496) demonstrates that there are four levers of coloniality: (1) control of the economy, (2) control of authority, (3) control of gender and sexuality, and lastly (4) control of knowledge and subjectivity. Ndlovu-Gatsheni elaborates that coloniality is entangled heterarchies, complex class formations and core-periphery divisions. Coloniality is realised in the continued patterns of the subjugation of the colonised by way of prevailing institutionalised racism and maintained hegemony of Eurocentric epistemologies (Grosfoguel 2002).

Grosfoguel (2011: 11) construes coloniality and modernity as two sides of the same coin, subsequently arguing that Eurocentric colonial culture is an ideology that is not limited to Europe, meaning that modernity is always constituted by coloniality 
(Grosfoguel 2002). Modernity has crucial implications for how the world conceives of social change, struggles against inequality, democracy and scientific disciplines, whereas coloniality is the lived experienced of subaltern groups to conceive the same (Grosfoguel 2002).

Universities continue to impart Eurocentric education imposed by the coloniser; the curriculum, practices of research, and anything related to knowledge production remain Eurocentric long after the colony has gained independence. This is a trend that reproduces itself through the colonial university that continues to produce graduates, and hence academics, that adhere to colonial standards.

Asante (2012: 33-47) defines Eurocentric education as a superstructure that seeks to impose European consciousness and ideas onto other people's consciousness. Eurocentrism is a pervasive ideology that sneaks into every aspect of life that attempts to erase the diverse history of peoples, to supplant their outlook on life and their understanding of the world (Mulder 2016).

Eurocentric ideas about education and the curriculum are the only recognised forms of knowledge(s) in South African universities. Everything else is relegated to the status of sub-knowledge or non-knowledge. This assessment takes into account the existing pockets of resistance of varying scholars, activists and solidarity networks in the global South, noting that although resisting and waging a relentless pushback, the system continues to throttle their voices. Mulder (2016: 6) emphasises that this reality indicates that colonisers suffer from an epidermisation of superiority, which is an ingrained belief that, conscious or unconscious, their whiteness entails superiority over all those who are not white. She explains that this unfounded sense of superiority does not arise through natural forces but rather is consequence of daily exposure to institutionalised racism upheld by colonised education. The legacy of coloniality in South African higher education generally, and the LLB curriculum in particular, gives rise to the calls for decolonisation.

\section{MOHLOMISM AND IP's INCENTIVE THEORY}

The central premise of modern copyright (and patent) law is that creators of innovative works need to be economically incentivised on the assumption that this incentive will encourage more innovation. Du Bois (2018: 22) provides a rationale for the incentive theory saying that it 
[a]dvocates promoting the creation of valuable intellectual works by granting property rights in such works since copyright, patent, and trade secret property protection provide the only adequate incentives for the creation of a socially optimal output of intellectual products.

It is accepted, according to this theory, that innovation only happens when works of intellectual property are incentivised by the protection against economic exploitation by others.

'Incentive' is interpreted in this narrow sense because it refers only to monetary reasons to create, meaning that it is seen as the driver of individual economic interests in the market (Dreyfuss \& Frankel 2015). The capitalist interpretation of 'incentive' suggests that the individual who is incentivised in monetary terms is the driver of innovation, given impetus by the capitalistic tenets of the Agreement on TradeRelated Aspects of Intellectual Property Rights (TRIPS) (Dreyfuss \& Frankel 2015). 'Incentive' is a justification that suggests that money is the strongest motivator of innovation. It is a singular and narrow economic discourse to argue that innovation happens only when works of intellectual property are economically incentivised (Sunder 2012).

Given that innovation occurred before the advent of intellectual property rights, and similarly profits and sustained innovation is present in areas with relatively weak intellectual property protection, it is illogical to perceive economic incentive as the only driver of innovation (Searle \& Brassell 2016). There is a need to problematise the narrow definition of incentive and questions its rationale; the Eurocentric rationale of the incentive theory should never be construed as means to generate profits because this reduces intellectual property law to a get-rich-or-die-trying scheme that negates the non-monetary aspects of life (Sunder 2012). Rather, law should enable citizens to live a good life and not merely protect private capitalist interests.

Intellectual property scholars should not insist on using the narrow lens of economic interests to construct a complete vision of intellectual property law. Human flourishing is dependent on the developing world's access to food, textbooks, and essential medicines and the capacity to earn a livelihood from one's intellectual contributions to our global culture. These are all aspects that supersede the narrow economic incentives lens that underpin the Eurocentric incentive theory (Sunder 2012). 
Ghosh (2006: 108) finds that intellectual property is commonly viewed as a matter of private law and private rights, whereas there are actually parallels between natural monopoly theory and theories justifying intellectual property that demonstrate the involvement of public law. The incentive theory predicts very little about the structure of intellectual property rights, except for the implication that intellectual property rights need to be as strong as possible in order to maximise incentives (Ghosh 2006). The incentive-to-innovate theory is either false or misguided in shaping the understanding of intellectual property systems (Ghosh 2006).

The non-binary nature of the debate on intellectual property calls for the development of the incentive to innovate theory, and for it to be expanded to reflect the epistemic inquiries of the subaltern. For example, the incentive theory falls short in justifying intellectual property when it comes to works of art that are created for the sake of art and not primarily because of the motivation that the incentive theory offers (Ncube 2017). There are seven attributes that make creative industries unique insofar as the incentive rationale is concerned, and the so-called 'starving artist' argument points to intrinsic motivation to create art instead of financial motivation (Searle \& Brassell 2000).

The argument against the incentive-to-innovate theory does not necessarily mean that artists do not want to be compensated for their works. ${ }^{3}$ However, the argument is that even though artists rightly demand to be remunerated for their works, it does not mean that artists will not produce art without a monetary incentive. This argument suggests that financial income is not proportionate to the rate of creation of creative products. The incentive theory is directed at fostering innovation whereas indigenous knowledge systems frequently aim to protect against exploitation of traditional cultural expressions, thus presenting a practical difference between Western IP protectionist habits and the needs of traditional cultural expressions to be protected from cultural imperialism (Du Bois 2018).

3 PEN Afrikaans. (2018, 29 November). South African authors protest against Copyright AmendmenBill.. Litnet.. https://www.litnet.co.za/south-african-authors-protest-against-copyright-amendment-bill/. A group of South African writers under the banner of the PEN Afrikaans organisation recently publicly rejected/opposed the South African parliament's draft Copyright Amendment Bill because the group claims that the Bill takes away some of the author's rights to make money from their works, by introducing concepts such as fair use and others, to South Africa's copyright regime. 
Roodt (2004: 163) insists that contemporary law faculties should actively investigate the central questions that cleave the discourse on indigenous knowledge(s) from the discourse on intellectual property law. The paucity of comparative studies incorporating African philosophies in intellectual property law is regrettable and calls for academia to change its thinking on this subject.

Intellectual property law, as it is currently taught today, is premised on systematic tension between the incentive to innovate and ubiquitous access to products of innovation. Sunder (2012: 30) argues that, '[f] or most critics of intellectual property law today, these two values: incentives and access, are the two that matter. Other values are subsumed by these two broad categories. This exposes how narrow the debate has become, as it is concerned with productivity which then translates into incentives.

In an effort to Africanise the incentive theory as taught in the LLB curriculum, Transmodernity proffers the African philosophy of Mohlomism. Sesanti (2014: 434) provides an incisive account on Mohlomism, defining its central tenet as the outlook of life among the Basotho; it is the lens that the people use to navigate various complex societal questions.

Historical accounts show that Mohlomi was a mentor to the King of Lesotho, Moshoeshoe I. Mohlomi would also travel around Southern Africa teaching people about his philosophy of truthfulness, justice, peace, the love of mankind and the pursuit of sane humanism (Sesanti 2014). When he was not travelling, Mohlomi ran a 'leadership academy' in southern Africa; he has been dubbed as the Socrates of Africa, because he best illustrates the brilliance of pre-colonial African leadership (Mahao 2015). The teachings of Mohlomi are crucial as he represents African intellect and wisdom prior to colonial contact, because he had never set eyes on a European nor was he influenced by Eurocentric epistemic traditions. ${ }^{4}$

The current LLB curriculum, in the legal philosophy modules, makes mention of most of the Western philosophers who lived during the time of Mohlomi. Due to deliberate erasure and epistemicide, the philosophical thinking of Mohlomi is not included in the LLB curriculum. Mohlomi's teachings were like those of Western thinkers aimed at the problems of his community, but naturally the circumstances of different communities can differ radically. Yet the Eurocentric South African

4 On the history of Mohlomi, see generally, Machobane, L. (1990). Government and Change in Lesotho, 1800-1966: A Study of Political Institutions. Place of publication needed: Macmillan. 
curriculum indiscriminately assumes that Western scholarship is suitable to regulate African situations and respond to African challenges.

The philosophy of Mohlomism is based not only on his thoughts as an individual because Mohlomi attributed his philosophy to the wisdom of the Supreme Being, Molimo and ancestral spirits, Badimo. This is a philosophy that is prevalent in various African cultures. Molimo, in isiNdebele is $u \mathrm{Zimu}$; this is what may be referred as God, or Allah or any higher power. The latter, Balimo, refers to ancestors or their spirit. In isiNdebele this is called Abezimu. There is a long history of Africa's reverence to both a higher power, that is God, as well as the power of ancestors, Balimo. Mohlomism is therefore a product of the mental and physical experience of the Basotho society (Sesanti 2014).

The most important aspects of the philosophy of Mohlomism that Transmodernity inserts into the incentive theory, and thereby the LLB curriculum, are the aspects of truthfulness, justice and the pursuit of sane humanism (Du Preez 2012). While innovation should be incentivised to stimulate economic growth and protect individual claims to the fruits of their intellectual labour, this should be done in light of what is true, what is just and what is humanely sane. For example, allowing a longer copyright duration bodes well for copyright owners, but not so well for the public domain. In this respect, Mohlomism invites an inquiry into whether it is more just and humanely sane to have a copyright endure for a longer or a shorter period.

Current Eurocentric modes of thinking agree that individual owners of patents are given the exclusive right to license their patents as they please. These rights are hardly ever curtailed by a social justice agenda, such as in an instance wherein an individual holds a patent for essential medicine that could be used cure outbreaks such as Ebola, Covid-19, and others.

The reality of strong protections for intellectual property rights holders/owners is cast in stone, notwithstanding Article 8.2 of the TRIPS agreement which provides that

[a]ppropriate measures, provided that they are consistent with the provisions of this Agreement, may be needed to prevent the abuse of intellectual property rights by right holders or the resort to practices which unreasonably restrain trade or adversely affect the international transfer of technology.

The concern of Article 8.2 is not social justice, neither is it the needs of the global 
community, let alone people on the underside, but rather the demands of free trade and the advancement of technology transfer. The Article is telling of the capitalist interests that underpin the global intellectual property regime as espoused by the TRIPS agreement (LenkaBula 2005). At the centre of decolonial articulations is the need to create a curriculum that breaks free from capitalist consumerist culture, which teaches students to be customers and consumers (Mbembe 2016). Even with the intervention of Article 7 which provides that

[t]he protection and enforcement of intellectual property rights should contribute to the promotion of technological innovation and to the transfer and dissemination of technology, to the mutual advantage of producers and users of technological knowledge and in a manner conducive to social and economic welfare, and to a balance of rights and obligations[,]

LenkaBula (2005: 40) argues that the patenting of life-forms serves the interests of Western and Euro-North industries, seeking to appropriate and privatise the wealth of biodiversity while neglecting the needs for food security and health-care of millions of Africans that are living under wretched poverty.

South Africa's competition commission has grappled with this Eurocentric protectionist attitude in the matter between Hazel Tau and Others $v$ GlaxoSmithKline and Boehringer Ingelheim, wherein the complainants alleged that the pricing model used for essential medicine by multinational pharmaceutical companies is exorbitant and thus responsible for the premature and avoidable loss of life (Avia, Berger \& Hartzenberg 2006). The commission found in favour of the complainants, referring the matter to the competition tribunal for ruling. The Hazel Tau case is a classic example of how global intellectual property regimes, notwithstanding articles 7 and 8.2 of TRIPS, lean towards strong protections of individualised holders of patents. The Doha Declaration on TRIPs and Public Health, the Agreement of the WTO General Council of 2003 and the decision of the TRIPs Council to permanently amend Article 31 of TRIPS in 2005, have increased the legal certainty on flexibilities available to developing countries. However, none of these amendments are laden with either a social justice imperative or any related intellectual property law justification (Avia, Berger \& Hartzenberg 2006).

The philosophy of Mohlomism teases out a debate whether the individual holding of patent, at the face of mass deaths, is objectively humanely sane and presenting of 
the love for humankind.

Given that the incentive to innovate is not chief in the creation of indigenous knowledge systems, the concepts of justice, peace, love and striving for sane humanism can be used as justificatory theories to describe the protection afforded to indigenous knowledge systems and traditional cultural expressions.

Odora-Hoppers (2001: 21-38) argues that the project of decolonising and transforming pedagogy '[needs to] expose the established hegemony of Western thought and beseech it to feel a measure of shame and vulgarity at espousing modes of development that build on silencing of all other views and perceptions of reality'. Colonial education deliberately ignores African philosophy and assumes that African people had neither a philosophy nor an epistemology, thus, inserting the ideas of Mohlomi into the curriculum in this way, deconstructs colonial education (Ramose 2004).

Mohlomism contributes to decolonisation, not by being inserted into the justificatory debate merely to provide a nuanced conception of the incentive theory, but to cure the theory of some of the characteristics which are alien to the African situation. One of the incentive theory's characteristics that is alien to the African situation includes the theory's over-reliance on the singular analogy of monetary remuneration as a driver of innovation. Mohlomism seeks to reverse epistemicide by asserting the black body as a Being among other Beings, worthy of producing knowledge and legal recognition.

Academics should be encouraged to grapple with the philosophy of Mohlomism in the copyright curriculum, just as they do with the ideas of male European thinkers. Mapesela (2004: 321) argues that the contestation about Basotho indigenous knowledge(s) being a science stems from a lack of knowledge about some Sesotho philosophies, contending that Sesotho philosophies should be inserted into higher education, and proposing that deconstruction should employed to illuminate some of the mysteries and hidden meanings that have surrounded these philosophies for a long time.

\section{BADIMO AND COPYRIGHT LAW'S AUTHOR}

The labour theory of property originates in the work of John Locke that says that a person owns their own labour and is entitled to the fruits of their labour (Craig 2002). This is the principle of first appropriation (Searle \& Brassell 2016). According 
to Locke, inventions and creations are products of an individual's toil and labour (Craig 2002 \& Ghosh 2006). The labour theory plays a major role in the recognition of modern intellectual property rights (Mostert 1987), although post-modern thinkers like Craig (2002: 495) have extensively deconstructed this thinking:

The doctrine of intellectual property is predicated on the principle that the creator of a work of intellect has an absolute and exclusive right to it, just as property as a tangible thing would grant unfettered dominion to the owner.

Roodt (2004:168) points out that '[f] ormal regimes [like the current labour theory] are characterised by adaptability, but individualised rights are not fully responsive to the cultural nature of traditional and indigenous knowledge'. The individualistic framework on which the labour theory is built proves inapt when responding to the African situation because the natural rights discourse begins and ends with an individualistic proprietarian focus (Craig 2002).

One antithesis to the current Eurocentric and individualistic labour theory is an engaged study of authorship in the context of African indigenous knowledge(s) or works that are products of such indigenous knowledge along with African modes of communal ownership that flow from these practices (Kaya \& Seleti 2013). A deepened study of African modes of communal ownership in relation to the work of authorship provides a richer perspective on the current labour theory. In Eurocentric scholarship, authorship is always a matter of an individual or individuals: an individual as an author or individuals in joint authorship. ${ }^{5}$

The fruits of one's labour, as defined by the labour theory, means that the community, in which authors work by way of African belief systems of Balimo and Molimo, fails to resonate with Locke's logic because the labour theory's 'fruits' does not take ancestors and the yet-to-be-born into cognisance. Equally, the concept of joint-authorship is inept to define a community because it does not include Badimo and the yet-to-be-born.

Sesanti (2014: 437) offers an Africanised definition of community: 'In African traditional culture, "community" is defined as the departed souls (the dead), the living and those yet to come (the unborn)'. This means that in African culture the

5 See section 1(1) of the Copyright Act 98 of 1978, the definition of an author in relation to various works from S1(1) (a) to (i), as well as section 21 (1) (a) of the Copyright Act 98 of 1978. 
death of a person does not break the bond that exists between the living and the dead, therefore the involvement of the dead. The amendment effected by IPLAA does not dismantle the individualism of modern intellectual property law nor does it address the particularities of Africa's unique situation. Instead it defines a community and indigenous works by fusing individual authorship with geographic proximity and with joint authorship framed in relation to cultural similarity. The intellectual Property Laws Amendment Act 28 of 2013, section 3(f) provides that 'conditions which distinguish them (indigenous communities) from other sections of the national community, and who identify themselves and are recognised by other groups as a distinct collective. Students rather need to be taught that an author of indigenous works is sometimes neither an individual nor a composite group individual, but a community that includes ancestors and the yet-to-be-born (Ginsburg 2002).

The definition of a community as representing the living, the dead, and the yet to be born does not find resonance in Eurocentric copyright law conceptions. The court in Cummins v Bond [1927] 1 Ch 167 (Chancery Division of the High Court of Justice, before Mr Justice Eve) grappled with this matter when a seer/medium (iSangoma), Miss Geraldine Cummins, sought an order interdicting the defendant, Mr Frederick Bligh Bond from publishing certain works written by the her, titled The Chronicle of Cleophas. The plaintiff had written the works while unconscious: her eyes were closed and she was not aware of what she was writing because she was engulfed by the ancestor-like spirit of Cleophas (Badimo). Frederick Bond claimed ownership of the work because it was written in his presence and was inspired therein by his spirit (or his ancestors/Badimo). The court was called upon to respond to three pertinent questions: (1) whether automatic-writing is indicative of the operations of ancestors in copyright authorship; (2) whether a court has any jurisdiction over departed souls (deceased authors or Badimo); and (3) whether the defendant (publisher) had a joint copyright ownership over the work.

The court's response to these three questions is telling of Eurocentric rejection of alternative epistemologies that move beyond the normative logic and reasoning of Eurocentric sensitivities. It found that the suggestions of ancestors as authors in copyright is laughable, likening the plaintiff's automatic writing to Samuel Taylor Coleridge's poem Kubla Khan: although Coleridge was under the influence of drugs (opium) he is still the author of the work, and so his state of consciousness at the time of writing is therefore immaterial. Consequently, the authorship of a work written by a person under the influence of Badimo fully vests in the medium and not the 
ancestor, because the court found that it does not have jurisdiction over Badimo, owing to its self-admitted ignorance on the functions and operation of ancestors. At face value, the court's findings look to be logical, but when articulated through a decolonial lens, they are an expression of colonial rigidity and rejection of different forms of knowing and enunciation, further deepening epistemic violence on the subaltern (Heleta 2016).

Intellectual Property Laws Amendment Act 28 of 2013, section 3(f) defines an indigenous community as:

[a]ny recognisable community of people originated in or historically settled in a geographic area or areas located within the borders of the Republic, as such borders existed at the date of commencement of the Intellectual Property Laws Amendment Act, 2013, characterised by social, cultural and economic conditions which distinguish them from other sections of the national community, and who identify themselves and are recognised by other groups as a distinct collective.

Intellectual Property Laws Amendment Bill 8B of 2010 defines an indigenous community as'[a]ny community of people currently living within the borders of the Republic, or who historically lived in the geographic area currently located within the borders of the Republic'. The legislative concept of community renders labour theory even less applicable to indigenous knowledge(s) because it makes it impossible for the communal authors to be either an individual or joint author as defined by the Copyright Act 98 of 1978.

Eurocentric intellectual property (specifically copyright law) regimes impose a concept of authorship that accommodates only single author, co-authors, jointauthors and communal authors. In African culture and mythology, authorship may also extend to ancestors and the yet-to-be-born, which should feature in teaching the concept of authorship in the LLB curriculum.

Geyer (2017:54) insists that a closer reading of section 28D (3) (c) of the Copyright Act shows that communities could be co-authors. A singular inferential reading of the Act means that Geyer is correct; however, in light of the labour theory and the subsequent definition of an indigenous community, the concept of joint-authorship, co-authorship is a misfit in a decolonial articulation in intellectual property.

Geyer (2010: 132-180) posits that the '[i]ndigenous community does not refer to the public or society in general, that is, to South Africans generally, but to a plurality 
of groups. The community needs to be understood as encompassing plural and nuanced factors, and not through a focus on fixed definitions (Geyer 2010). Geyer (2010: 132-180) defines the image of community as one that '[c]an inter alia be defined in terms of the area in which a group of people lives or in terms of a group's common background or shared interests'. Although there have been newer drafts of this Bill following from the text relied on by Geyer (2010), the definition of a community does not seem to change.

The Copyright Act always defines an author as a person denoting an individual, which means that the Copyright Act views authorship only as that which can be attributed to an individual or individuals. The Act also uses the word 'co-authors' in the case of joint authorship. The Intellectual Property Laws Amendment Act 28 of 2013, Section 3 (a) (k) provides a slight deviation from the Copyright Act's individualistic definition in saying that authorship of indigenous work includes the indigenous community from which the work originated and acquired its traditional character.

\section{CONCLUDING REMARKS}

In rejecting Western values, therefore, we are rejecting those things that are not only foreign to us but that seek to destroy the most cherished of our beliefs - that the cornerstone of society is man himself - not just his welfare, not his material wellbeing but just man himself with all his ramifications. We reject the power-based society of the Westerner that seems to be ever concerned with perfecting their technological know-how while losing out on their spiritual dimension. (Biko 1971: 46-47)

Coloniality marks the continued patterns of the subjugation of the colonised, through the enactment of global racial hierarchy and the hegemonic Eurocentric epistemologies in the present-day world system (Grosfoguel 2002). The reality of coloniality is such that there needs to be continuous work to decolonise all sectors of society. Higher education, as a space for knowledge production, teaching and learning, is at the centre of epistemic decolonisation (making universities to become very important in the quest to decolonise South Africa); furthermore, the intellectual property law module presents workable avenues for decolonial articulations which may lead to the gradual transformation of the LLB curriculum. 
A discussion of Morena Mohlomi's philosophies, when inserted into intellectual property pedagogy, contributes to decolonisation by way of re-membering dismembered colonised bodies. A decolonised conception of communal modes of African peoples and the concept of African Community, needs to begin at a space wherein it is understood that in African philosophy, authorship of traditional and indigenous works does not only rest with the living, but also goes to the dead as well as those yet to be born. 


\section{References}

Asante, M. (2012). Reconstituting curricula in African universities: In search of an Afrocentric design. In C. Alvares \& S.S. Faruqi (eds), Decolonising the university: The emerging quest for non-European paradigms (pp. 33-47). Pinang, Malaysia: Penerbit Univirsiti Sains Malaysia.

Avia, T., Berger, J. \& Hartzenberg, T. (2006). The ability of select sub-Saharan African countries to utilise TRIPs Flexibilities and Competition Law to ensure a sustainable supply of essential medicines: A study of producing and importing countries. UNCTAD/ICTSD project on IPRs and Sustainable Development: 1-48.

Bhambra, G. (2014). Post-colonial and decolonial dialogues. Postcolonial Studies Journal, 17(2): 115-121.

Biko, S. (1996). I write what I like: Selected writings. Chicago: University of Chicago Press.

Cornell, D. \& Van Marle, K. (2005). Exploring Ubuntu: Tentative reflections. African Human Rights Law Journal, 5(2): 195-220.

Cornish, W.R. (2019). Intellectual property: Patents, copyright, trademarks and allied rights (9th edition). London: Sweet \& Maxwell.

Council on Higher Education. (2017, November). Decolonizing the Curriculum: Stimulating Debate. Briefly Speaking, 3.

Craig, C. (2002). Locke, labour and limiting the author's Right: A warning against a Lockean approach to copyright law. Queen's Law Journal, 28(1): 1-60.

Dlamini, C. (1992). The law teacher, the law student and legal education in South Africa. South African Law Journal, 109(4): 595-610.

Dreyfuss, R. \& Frankel, S. (2015). From incentive to commodity to asset: How international law is reconceptualizing intellectual property. Michigan Journal of International Law, 36(557): 557-601.

Du Bois, M. (2018). Justificatory theories for intellectual property viewed through the Constitutional prism. Potchefstroom Electronic Journal (PER), 21: 1-38.

Du Preez, M. (2012). Tafelberg Short: A chief is a chief by the grace of his people: Once we had leaders. Cape Town: Tafelberg.

Geyer, S. (2010). Towards a clearer definition and understanding of 'Indigenous Community' for purposes of the Intellectual Property Laws Amendment Bill, 2010: An exploration of the concepts 'Indigenous' and 'Traditional'. Potchefstroom Electronic Law Journal (PER), 13(4). 127- 180. 
Geyer, S. (2017). Copyright in traditional works: Unravelling the Intellectual Property Laws Amendment Act of 2013. South African Mercantile Law Journal, 29(1): 43-64.

Ghosh, S. (2006). The intellectual property incentive: Not so natural as to warrant strong exclusivity. SCRIPT-ed, 3(2): 97-108.

Ginsburg, J. (2002). The concept of authorship in comparative copyright law. DePaul Law Review, 52: 1063-1092.

Grosfoguel, R. (2002). Colonial difference, geopolitics of knowledge, and global coloniality in the modern/colonial capitalist world-system. Review Fernand Braudel Center, 25(3): 203-224.

Grosfoguel, R. (2003). The structure of knowledge in westernized universities: Epistemic racism/sexism and the four genocides/epistemicides of the Long 16th Century. Human Architecture: Journal of Sociology and Self-Knowledge, 11(1): 73-90.

Grosfoguel, R. (2011). Decolonizing post-colonial studies and paradigms of politicaleconomy: Transmodernity, decolonial thinking, and global coloniality. Journal of Peripheral Cultural Production of Luso-Hispanic World, 1(1): 1-38

Gordon, L. (2014). Disciplinary decadence and the decolonisation of knowledge. Africa Development, 39(1): 81-92.

Heleta, S. (2016). Decolonisation of higher education: Dismantling epistemic violence and Eurocentrism in South Africa. Transformation in Higher Education, 1(1): $1-8$.

Himonga, C. \& Diallo, F. (2017). Decolonisation and teaching law in Africa with special reference to Living Customary Law. Potchefstroom Electronic Law Journal (PER), 20(1): 1-19.

Kaya, H. \& Seleti, Y. (2013). African indigenous knowledge systems and relevance of higher education in South Africa. The International Education Journal: Comparative Perspectives, 12(1): 30-44.

Kelbrick, R. (2008). The need for different perspectives. International Review of Intellectual Property and Competition Law, 39(8): 884-886.

Kumalo, S. (2018) Explicating abjection - historically white universities creating natives of nowhere? Critical Studies in Teaching and Learning, 6(1): 1-17.

LenkaBaula, P. (2005). The social and ethical implications of Article 27 of the Agreement on Trade-Related Aspects of Intellectual Property Rights (TRIPS), on African communities, biodiversity and indigenous knowledge. Journal of Theology 
for Southern Africa, X( 122): 36-56.

Madlingozi, T. (2017). Social justice in a time of neo-apartheid constitutionalism: Critiquing the anti-Black economy of recognition, incorporation and distribution. Stellenbosch Law Review, 1(123): 123-147.

Mahao, N. (2015). The King Moshoeshoe I Memorial Lecture. Lesotho Law Journal. $22(1 \& 2) .1-14$.

Maldonado-Torres, N. (2016). Outline of Ten Theses on Coloniality and Decoloniality. Retrieved from the Frantz Fanon Foundation. www.frantzfanonfoundation.com $1-37$.

Manzini, N.Z. (2017). Reflections on the presence of police and private security at the University of the Witwatersrand, Johannesburg. Agenda, 33(3-4): 78-88.

Mapesela, M. (2004). The Basotho indigenous knowledge (IK): Do we understand it well enough to employ it as a tool in higher education teaching? South African Journal for Higher Education, 18(3): 316-326.

Mbembe, A. (2016). Decolonising the university: New directions. Arts \& Humanities in Higher Education, 15(1): 29-45

Modiri, J. (2014). The crises in legal education. Acta Academica, 46(3): 1-24.

Mostert, F. (1987). The development of the Natural-law Principle as one of the principles underlying the recognition of intellectual property: A historical survey from Roman law to modern-day law. South African Law Journal, 104(3): 480-501.

Motshabi, K. (2018). Decolonizing the university: A law perspective. Strategic Review for Southern Africa, 40(1): 104-115.

Mulder, L. (2016) Frantz Fanon, internalized oppression and the decolonization of education. Paper presented at the launch of the journal Commentaries, University of St Martin, 2016. African Journal of Political Science, 8(1): 1-29.

Ncube, C.B. (2016). Decolonising intellectual property law in pursuit of Africa's development. WIPO Journal, Volume 8. No.1. 34-40.

Ncube, C.B. (2017). Calibrating copyright for creators and consumers: Promoting distributive justice and Ubuntu. In R. Gilbin \& K. Weatherall (eds), What if we could reimagine copyright? (pp. 254 - 279): Canberra: ANU Press. 
